\title{
Rural Entrepreneurship Development as A Catalyst to Employment Generation and Poverty Alleviation in Oyo State, Nigeria
}

\author{
Folorunso, Olufunmilola. Olufunmilayo \\ Department of Business Administration and Management Studies, The Polytechnic, Ibadan, Nigeria
}

\begin{abstract}
The study examined the effect of rural entrepreneurship development on poverty alleviation and employment generation in Oyo State, Nigeria. The assortment of ten LGA was purposive due to their ruralness. In each of the purposively selected LGAs, fifty (50) entrepreneurs were selected through simple random sampling technique from their co-operative societies, totaling five hundred (500) respondents. Data were sourced via a structured questionnaire and personal interview, while data analysis was performed with aid of simple percentage, frequency, weighted mean score, and ordinary least square. Result demonstrated that chance to create own fortune, determines the degree of their impact on rural business opportunities, profit attraction, more competitiveness in the region, self/dependent lifestyle, and continue the family tradition are important factors motivating them to build their business in rural areas. Result also showed that accessibility to, and unavailability of proper information is important challenges facing entrepreneurship development. Also the absence of government policies, hardships in availing government strategies, technological center, and lack of access to resources, transportation center are important challenges facing entrepreneurship development in the research area. Results also demonstrated that entrepreneurship development has a significant impact on poverty alleviation and employment generation. Subsequently, a study recommended that financial institution should be established in all rural areas throughout the Nation to dish free loans to rural areas and Ministry of Rural Development and Land Reform should be in increasing credit finance as well as borrowing via informal networking
\end{abstract}

Keywords: Rural Entrepreneurship, Poverty Alleviation, Employment Generation, Financial Institution, LGAs.

DOI: $10.7176 / \mathrm{JESD} / 11-10-06$

Publication date:May $31^{\text {st }} 2020$

\section{Introduction}

Unemployment and poverty, inter socio issue that is related, are tendency which affects individuals in different depths and levels at different moments and phases of existence. The amount of association between poverty and also in unemployment from the developing nations is frequently a matter of considerable debate. There's really no nation that's totally free of unemployment and poverty. The significant difference is the level and pervasiveness of this blight that is similar. The current statistics from the National Bureau of Statistics show over 90 million young people about 56 percent are unemployed and 9 percent are underemployed leaving only 35 percent (Eso, 2015).

Insurgency, Political Violence, Social Insecurity, and crimes in Nigeria might be traceable to implications of the elevated rates of unemployment among youths. It's therefore essential to be aware that these threats of unemployment, social insecurity and offenses are the results of the underdevelopment of rural entrepreneurship. To support this statement, Ocheni, Atakpa, and Nwankwo (2012) confirmed that undergrowth of the rural communities has forced more qualified individuals to migrate from the rural communities into the significant towns and cities such as greener pasture, believing that wealth has always been concentrated in and around urban areas. There's the overall agreement between researchers who probably the most important components of the economic development plan are rural entrepreneurship (Adelakun, 2013; Cavanagh, Shaw and Wang, 2013; Frazier, Niehm and Stoel, 2012; Kolawole and Torimiro, 2005).

Rural entrepreneurship signifies the same as industrialization (Saxena, 2012). Rural entrepreneurship might be regarded as an effort to create the direction for risk-taking proper to chance, as well as to mobilize human, material and fiscal resources so as to fulfill the job in rural areas. According to Osuagwu (2006), entrepreneurship is the introduction of a business that introduces serves, generates, or uses a market, or uses a brand new technology in a rural environment. Additionally, based on Stathopoulos, Psaltopoulos, and Skuras (2004), rural entrepreneurship is the creation of new employment opportunities in rural areas, through the creation of new business ventures. From all of these views, entrepreneurs can be seen as people residing in rural locations.

In latest years developments like the process of globalization, location and technological change have been observed in rural areas (Sopiko, Polina and Ani, 2013). Rural destinations offer substantial attractions to businesses. Several reasons for conducting business in rural areas include: cost saving, lower competition, and a climate and that enhance less stressful working environment. According to Anyadike, Emeh, and Ukah (2012), rural entrepreneurship development has been regarded as a bastion of employment creation, Poverty Alleviation, and 
Technological Development in Nigeria. Brydenand Hart (2005) also noted that activity in rural areas helps to streamline the economic network, thus avoiding dependence on monaural production and consequently being in a position to offer a range of services.

\section{Statement of Problem}

The attempts of the Nigerian government and people of other developing nations haven't yielded commensurate returns with regards to poverty reduction and giving a better life to the people. The scourge of poverty remains ravaging developing nations, and seem to be more critical in the rural areas, as statistics show that, as at 2011, the poverty rate from Nigeria, for example, stood at 54. 4 percent and out of this, rural dwellers carried the highest percentage of 63.3percent (Ighodalo, 2012). According to Small bone and Welter (2006), some typical characteristics of the rural environment, the non-availability of business premises, inadequate transport infrastructure, little size local markets, features of rural labor markets, and non-accessibility to data and fund depart. The rural area typical characteristics mentioned previously add trouble in attracting entrepreneurs and workers. Addressing the issue of poverty among rural dwellers throughout entrepreneurship has thus become imperative, given the substantial proportion of people affected and its implications for the country's socio-economic development.

It should be noted that the focus of research on entrepreneurship has been largely on general entrepreneurship, while studies on rural entrepreneurship have been exploratory in nature. This study, therefore, adopts an approach to the study of rural entrepreneurship in Oyo state. Owing to the objective of the issues of research is to investigate the impact of entrepreneurship development on employment generation and poverty reduction in rural areas in Oyo State, Nigeria.

\section{Research Aims}

The primary objectives of this study are:

i. to investigate the motivational factors of rural entrepreneurs,

ii. to identify challenges facing rural entrepreneurship development,

iii. to examine the extent entrepreneurship has an impact on poverty alleviation,

iv. to examine the extent entrepreneurship has an impact on employment generation

\section{Research Hypotheses}

The following hypotheses are formulated in null type for the study

Ho1: Rural entrepreneurship has no impact on poverty alleviation

Ho2: Rural entrepreneurship has no impact on employment generation

\section{Justification for the research}

This work will contribute to the multiple spheres of research and practical use. It'll make an input to existing rural research by introducing a view on rural entrepreneurship development, challenges and opportunities from the perspective of entrepreneurs' contrasts with the common economics and policy viewpoint. Second of all, this research will be of value to entrepreneurs who are considering conducting business in rural areas, because it will let them know in advance what difficulties to anticipate, as well as where to look for opportunities and how to possibly exploit them. Thirdly, the paper will shed light on what rural businesses are actually worried about, therefore assisting policy-makers with how to enhance business activity in country locations so as to curtail a high rate of unemployment and poverty level.

\section{Concept of Entrepreneurship}

Promoting activities is a fundamental approach to sustainable economic development. Entrepreneurship is argued to be a feasible alternative to industrial recruitment and an economically sustainable development approach (Petrin, 1994). Entrepreneurship is a process which might develop one Entrepreneur or enterprise with the most important goal is to earn a profit using scarce resources more than likely under private ownership. According to Adenutsi (2009), Entrepreneurship is defined as the identification of brand new business opportunities and the mobilization of economic resources to initiate a brand new business or reevaluate an existing business, under the conditions of doubts and dangers, for the aim of earning profits under private ownership. And on the other hand, entrepreneurship is concerned about generating long term value and generates regular cash flows on a person or the group of people for the future throughout the practice of imagination, initiative, and innovation for the aim of maximizing gains and minimizing danger with the perspective of long term expansion. Entrepreneurial activity has been found to have a strong effect on financial growth and job creation (Marshall and Samal, 2006). The creation of new enterprises is encouraged due to a thought that entrepreneurs and tiny businesses reinvigorate markets (Gartner, Shaver, Carter, and Reynolds, 2004). 


\section{Rural Enterprise Development Programs in Nigeria}

The rural entrepreneurship development program became a comparatively new and important research topic around the world. Many researchers have the opinion that encouraging medium and small businesses in rural areas will be the needed development approach to fight against poverty in developing nations. In Nigeria, governments have put in place policies and programs directed in entrepreneurship development, as a method of employment generation, poverty alleviation, and rapid economic development. The Significant programs according to Paul, Datong, and Bagobiri (2014) are; National Accelerated Food Production Programme and the Nigeria Agricultural and Cooperative Bank in 1972, Operation Feed the Nation: to educate farmers in rural areas how to utilize modern farming tools from 1976," Green Revolution Programme: to reduce food importation and increase local food production from nineteen seventy nine, Directorate of Food, Roads and Rural Infrastructure in 1986, National Directorate of Employment in 1987, Family Service Programme and the Family Economic Advancement Programme in 1993, National Poverty Eradication Programme in the year 2001, Alleviation Programme, and National Economic Empowerments and Development Strategy in 2004, the seven-stage Agenda, 2007, Integrated Community Development Project, Economic Empowerment of States and Development Strategy and also many more. Unfortunately, these laudable programs died along the authorities initiated them without realizing the effects of boosting rural entrepreneurship.

\section{Relationship between rural entrepreneurship development, job creation, and poverty alleviation.}

Rural entrepreneurship development has been given priority to reinforce inclusiveness as a country progressed to become an advanced cosmopolitan nation. The attention of rural entrepreneurship development has been to uplift the wellbeing of rural entrepreneurs and stimulate economic actions based on land and natural resources. Emphasis was given to boosting utilization of contemporary technology, empowering rural entrepreneur community, encouraging community-driven cooperatives, providing quality rural basic infrastructure and basic services. According to Shaw, Cavanagh, and Wang (2013), rural entrepreneurship development is a process of quality of life of the Men and Women who are currently living to the rural areas, from their very own ascribed status into a brand new. Status. At the view of Matanmi and Amiden (2005), if Nigeria desires to move from the upsetting high degree of ravaging and unemployment degree of poverty, adequate attention needs to be given to the rise of entrepreneurship. They concluded that Nigeria remains in the doldrums due to a combination of ignorance, low capacity building and lack of reinforcement of entrepreneurship.

According to Silvinski (2012), a higher average rate of entrepreneurship in a country corresponds to bigger declines in actuality; each $1 \%$ increase in entrepreneurship corresponds to a decrease in the poverty rate. It's so posed that the best way for authorities to improve economics is by encouraging rural entrepreneurship. In his own contribution, Ariyo (2008) noted that when Nigeria wants to achieve its whole potential with regards to economic and social development, it can't afford to ignore the significance of its indigenous entrepreneurs and the contributions they make to the nation's economy. Igwes, Adebayo, Olakanmi, Ogbonna, and Aina (2013) clarified rural entrepreneurship as a strong engine of financial growth and wealth creation for most developing nations, which is crucial for enhancing the quality, number, and variety of employment opportunities for the poor. Fapohunda (2012) also asserted that the informal sector contributes to the national economics with regards to increased output and employment creation by providing production points for a high number of those who might not be in a position to secure paid work in a formal sector.

According to Onyenechere (2010), the informal sector serves as a platform for income generation to unskilled and semiskilled workers who otherwise will be unemployed. Consequently, the informal sector has been implicated in employment creation and poverty alleviation. The work of Kolawole and Torimiro (2005) affirmed that rural entrepreneurship development creates employment opportunities, forestall rural-urban drift and isolation. Equally, Paul et al. (2014) reiterated that promoting rural entrepreneurship actions are significant strategies for sustainable economic development. Dabson (2001) also fund the rural entrepreneurship development provides the opportunities to products that encourage traditions of quality and craftsmanship, connecting to nature and a feeling of culture and place.

\section{The Challenges of Entrepreneurship in Rural Setting}

The following are the challenges facing Entrepreneurship in rural surroundings (Jerome \& Bambur, 2013):

i. Declining employment opportunities in main industries, as a consequence of structural modification, intensified by changes in coverage resulting from increased population. This emphasizes the necessity to take measures to stimulate economic activities with employment generating potential in rural areas.

ii. An aging population, associated with the migration of young people and also a migration of men and women, in several cases, which in conjunction affects the supply of entrepreneurs.

iii. Difficulties in maintaining a critical mass of facilities to encourage economic development, including a wide range of business services. 
iv. Increased requirement for conveniences on the portion of urban residents, the focus was shifted from rural growth to an increased need by the metropolitan lands on the demands for conveniences, rendering the rural area without conveniences that can ease entrepreneurship.

v. Sources of economic success, like lively SME clusters. The further other are seen making can propel an entrepreneur to foster ahead, where there's no challenging situation is a setback on the portion of entrepreneurs.

vi. Deficiency of Technical knowhow; rural entrepreneurs are without technical experience of the new area they want to venture into, this a challenge.

vii. Capacity Utilization. The inability to utilize capacity suggests under-utilization for the ability available for entrepreneurship.

viii. Poor Infrastructure; this infrastructure readily available, are obsoletes or is no longer in use.

\section{Theoretical Review}

This analysis anchors on Thomas Cochran's theory of entrepreneurship and Schumpeter's theory of Economic Development because these theories are related to the analysis.

\begin{tabular}{|c|c|c|}
\hline \multicolumn{2}{|c|}{ Theories of Microfinance } & Source \\
\hline $\begin{array}{l}\text { Thomas } \\
\text { Cochran's } \\
\text { theory of } \\
\text { entrepreneurship }\end{array}$ & $\begin{array}{l}\text { sThomas Cochran's theory emphasizes the effect of Culture as a crucial } \\
\text { component in dictating entrepreneurial behaviour and the resultant effects on } \\
\text { rural areas. He postulated that the environment where an individual is } \\
\text { brought up determines the impulse of the individual. }\end{array}$ & $\begin{array}{l}\text { Akanwa } \\
\text { and Agu } \\
(2005)\end{array}$ \\
\hline $\begin{array}{l}\text { The theory of } \\
\text { Economic } \\
\text { Development }\end{array}$ & $\begin{array}{l}\text { The theory of Economic Development Schumpeter develops a theory that } \\
\text { predicts the eventual death of capitalism and the eradication of the } \\
\text { entrepreneurial role. The functions of the entrepreneur are to reform the } \\
\text { patterns of production by exploiting inventions or new technology in the } \\
\text { production of a commodity, to open new sources of materials and new outlets } \\
\text { for products, and to reorganize the business. As a consequence of these } \\
\text { activities, new businesses are formed and old ones die. Capitalism results } \\
\text { from the action of entrepreneurs. This is what Schumpeter calls the practice } \\
\text { of"Creative Destruction. "The entrepreneurial function is eventually reduced } \\
\text { to regular operations, and bureaus and committees replace individual action. }\end{array}$ & $\begin{array}{l}\text { Schumpeter } \\
\text { (1951) }\end{array}$ \\
\hline
\end{tabular}

\section{Conceptual Framework}

\section{Implementation of Rural Entrepreneurship \\ Development Programmes:}

National Accelerated Food Production Programme

Economic Empowerments and Development Strategy (NEEDS).

The 7- point Agenda

Integrated Community Development Project

State Economic

Empowerment and Development Strategy (SEEDs) E.t.c

Figure 1: Conceptual Model

Source: Author's computation

\begin{tabular}{|l|l|}
\hline $\begin{array}{l}\text { Rural } \\
\text { Transformation } \\
\text { : Increased in } \\
\text { social amenities } \\
\text { Access to market }\end{array}$ \\
\begin{tabular}{|l|l|} 
Capacity \\
utilization \\
Technical know \\
-how. E.t.c
\end{tabular} & $\begin{array}{l}\text { Rural } \\
\text { entrepreneur } \\
\text { s' } \\
\text { performance } \\
\text { :Employment } \\
\text { generation } \\
\text { and Poverty } \\
\text { Alleviation }\end{array}$ \\
\hline
\end{tabular}

Rural
Rural entrepreneur performance :Employment Alleviation 
Figure 1 presents a summary diagram of the causal model for the prediction of job generation and poverty alleviation in Oyo State through entrepreneurship development. The model specifies the impact of entrepreneurship development on employment generation and poverty alleviation.

\section{Methodology}

Research Design: The survey research design was utilized because research is comparatively easy to administer and could be developed in less time (Mogenda and Mogenda, 2003).

Population of the study: Ten rural Local Government Areas (LGAs) of Oyo State, namely:Afijio, Irepo, Itesiwaju, Iwajowa, Olorunsogo, Surulere, Orire, Ibarapa North, Ogo -Oluwa and Saki East with population of 134,173; 13,$9012 ; 145,920 ; 287,221 ; 92,739 ; 126,692 ; 170,858 ; 101,092 ; 225,561$ and 125,026 correspondingly.

Sampling and Sample Size: The selection of ten LGAs was purposive due to their ruralness. In each one of the purposively selected LGAs, fifty (50) entrepreneurs were selected through simple random sampling procedure from their Co-operative Societies, totaling five hundred (500) respondents.

Data Collection Instruments. The data collection tools for the analysis were structured questionnaires and personal interviews. The research instruments were administered and retrieved personally by the researcher with the help of 3 research assistants.

Validity and Reliability of Instruments. The Test-retest procedure was utilized in order to establish the credibility of this instrument while the validity of the tool was determined through the face and content validities wherein the tools were given to professionals for evaluation and evaluation.

Method of Data Analysis. Data were analyzed with the help of simple percent, frequency, weighted mean score, and routine least square.

Model Specification

To examine the effect of entrepreneurship development on poverty alleviation and employment generation, mathematically, the following models are expressed as follows;

Model I

Poverty Alleviation $=\mathrm{f}(\mathrm{X} 1$,$) ....equ 1$

Poverty Alleviation $=\beta 0+\beta 1 \mathrm{X} 1+\mu \mathrm{I} \ldots .$. equ 2

Model II

Employment Generation $=\mathrm{f}(\mathrm{X} 1,) \ldots .$. equ 3

Employment Generation $=\beta 0+\beta 1 \mathrm{X} 1+\mu \mathrm{i} \ldots$. equ 4

where;

A priori expectation is $\beta 1[0$

$\mathrm{X} 1=$ Rural entrepreneurship development.

$\mu \mathrm{i}=$ Disturbance Term

$\beta=$ Intercept

$\beta 1=$ Coefficient of the independent variable.

\section{Results and Discussion}

\section{Analysis of Demographic Characteristics of Respondents}

This section described the demographics factors of respondents attempted. The ages of the majority of respondents sampled ranged from 48 to 70 years with a mean of 57.8 years and a standard deviation of 15.2. The majority of the respondents sampled are female, while over 80 percent of respondents migrated from other towns for the goal of a business. This connotes that the majority of active and full of energy youths have migrated to cities for a much better life, although the majority of entrepreneurs constitute the largest proportion of individuals. This result is consistent with Sajuyigbe and Fadeyibi (2017) which all of the rural entrepreneurs are very old and not full of energy and active. The younger ones have migrated to towns and cities for green pasture. The degree of education of the respondents ranged from school to postgraduate. Results revealed that over 70 percent of the sampled respondents have a primary school education, although only $5 \%$ of the respondents consumed post-secondary education. This implies that the majority of marketers are sack illiterate.

The implication of this finding is the fact that educated ones who supposed to change entrepreneurship have migrated to cities and towns for greener pasture. Regardless of various approaches implemented into the development of the rural areas and colossal quantity of cash invested and many professional agencies created area standards still remain very low in comparison with urban ones. This is in accordance with National Census reported that over 80 percent of the national population living in the rural areas have moved to urban cities thanks to poor development of facilities and this has made the rural entrepreneurship development extremely difficult to reach its potential. This menace scenario could impede Nigeria from attaining the vision of Sustainable Development Goals (SDGs) of 2030. 
Table 2. Distribution of respondents by factors motivating Rural Entrepreneurs

\begin{tabular}{|l|l|l|}
\hline Statement & Agreed & Disagreed \\
\hline Opportunity to make own Fortune & $365(100 \%)$ & - \\
\hline $\begin{array}{l}\text { I was having better exposure / informed so that I thought of seizing that } \\
\text { opportunity }\end{array}$ & $302(82.7 \%)$ & $63(17.3 \%)$ \\
\hline Economy was Competitive & $295(80.8 \%)$ & $70(19.2 \%$ \\
\hline Circumstances/ situations are conducive to become an entrepreneur & $35(9.5 \%)$ & $330(90.5 \%)$ \\
\hline Impressive profit attraction & $287(78.6 \%)$ & $78(21.4 \%)$ \\
\hline Ample Opportunities were available & $299(81.9 \%)$ & $66(18.1 \%)$ \\
\hline To continue the family tradition & $203(55.6 \%)$ & $162(44.4 \%)$ \\
\hline To possess self/dependent lifetime & $308(84.3 \%)$ & $57(16.7 \%)$ \\
\hline I was being able to arrange and administer the factor of production & $287(78.6 \%)$ & $78(21.4 \%)$ \\
\hline $\begin{array}{l}\text { Fluctuations in earnings /To prevent seasonal earnings (income } \\
\text { variations) }\end{array}$ & $255(69.8 \%)$ & $110(30.2 \%)$ \\
\hline This was my last option /resort in life & $307(84.1 \%)$ & $56(16.9 \%)$ \\
\hline
\end{tabular}

From table 2, all respondents agreed that the chance to create own fortune is a big factor motivating them to set their businesses in rural areas. This connotes that rural entrepreneurship is a tool to wellbeing and economic wellbeing of people living in relatively isolated and sparsely populated areas. The analysis consistent with prior studies in which rural entrepreneurship is a platform for income generation and poverty alleviation (Olowookere \& Elegbeleye, 2015; Adelakun, 2013; Paul et al., 2014). 302(82.7\%) of the respondents agreed that the level of their exposure to rural business opportunities is an important factor that inspires them whilst only $63(17.3 \%)$ of the sampled respondents disagreed with assertion. Over ninety percent of the respondents disagreed that situations are conducive to become an entrepreneur in the rural areas is an inspiring factor, while only 9.5percent of them agreed that situations are conducive to become an entrepreneur in the rural areas is an inspiring factor. This means that rural entrepreneurs in Oyo State are facing social conveniences challenges syndrome. Most of the respondents agreed that profit attraction, more aggressive in area, self/dependent lifestyle and continue family traditions are important factors motivating them to be rural entrepreneurs. This implies that if rural entrepreneurship can be developed by providing social amenities, it'll create job opportunities; forestall rural-urban drift and isolation.

Table 3. Distribution of respondents by challenges facing Rural Entrepreneurs

\begin{tabular}{|l|l|l|l|}
\hline Statement & Observed & $\begin{array}{l}\text { Weighted Meanked } \\
\text { Score }\end{array}$ & Ranked \\
\hline Getting Community / social support & 365 & 2.12 & $13^{\text {th }}$ \\
\hline Getting members of the family service & 365 & 1.98 & $14^{\text {th }}$ \\
\hline Availability of funds & 365 & 4.91 & $1^{\text {st }}$ \\
\hline Non- availability of material and equipment & 365 & 4.87 & $2^{\text {nd }}$ \\
\hline Location advantage & 365 & 3.12 & $12^{\text {th }}$ \\
\hline Lack of managerial abilities & 365 & 3.95 & $11^{\text {th }}$ \\
\hline Lack of access to correct information & 365 & 4.10 & $7^{\text {th }}$ \\
\hline Availing training in business and allied activities & 365 & 3.98 & $10^{\text {th }}$ \\
\hline Non- resource availability & 365 & 4.15 & $5^{\text {th }}$ \\
\hline Transportation center & 365 & 4.11 & $6^{\text {th }}$ \\
\hline Scarcity of power & 365 & 4.09 & $8^{\text {th }}$ \\
\hline Changes around the village & 365 & 3.12 & $3^{\text {rd }}$ \\
\hline $\begin{array}{l}\text { Lack of Govt. facility / regulations / schemes / difficult at } \\
\text { availing Govt. schemes }\end{array}$ & 365 & 4.21 & $9^{\text {th }}$ \\
\hline Competition in the market & 365 & 3.99 & $4^{\text {th }}$ \\
\hline Technological changes & 365 & 4.19 & \\
\hline
\end{tabular}

By Table 3 above, it may be deduced that accessibility of funds is $\mathrm{s}$ important to challenge facing rural marketers with the greatest weighted mean score of 4.91. This means that rural entrepreneurs are afflicted by financial exclusion syndrome. The analysis corroborates prior studies that finance and Loans have been inaccessible to many rural areas in Nigeria because individuals lack collateral, business plan, diversion of the loan granted and absence of banks culture (Sajuyigbe, 2017, Kolawole and Torimiro, 2005). Non availability of material and equipment was ranked 2nd with weighted mean score of 4.87, followed by lack of government facility/regulations /schemes / difficult in availing government Schemes, technological changes, no access to resources, transportation facility, no access to correct information, lack of power, while getting members of the family assistance was ranked the lowest with a weighted average score of 1.98. This connotes the above points expect family and social support are important challenges confronting rural entrepreneurship development in Oyo State. The study is consistent with Sajuyigbe and Fadeyibi (2016) that lack of infrastructural facilities; insufficient 
access to financing, no availability of healthcare and the lack of effective communication systems are factors hinder rural entrepreneurship development in Nigeria. In another study, Uwajumogu, Ogbonna, and Agus (2014) confirm the rural region is disadvantaged because of access to finance, infrastructure and social amenities and lack of resources that are effective. Paul et al. (2014) also reaffirmed that financial exclusion, lack of infrastructure, lack of access to information and non-access to resources are the most factors militating from rural entrepreneurship development in Nigeria.

Table 4: Effect of Rural Entrepreneurship on the poverty alleviation

\begin{tabular}{|c|c|c|c|c|c|c|c|}
\hline Model & $\mathrm{R}$ & R Square & $\begin{array}{l}\text { Adjusted R } \\
\text { Square }\end{array}$ & \multicolumn{2}{|c|}{ StandardError of the Estimate } & \multicolumn{2}{|c|}{$\begin{array}{l}\text { Durbin- } \\
\text { Watson }\end{array}$} \\
\hline 1 & $.646^{\mathrm{a}}$ & .417 & .416 & \multicolumn{2}{|r|}{.43000} & \multicolumn{2}{|r|}{1.905} \\
\hline \multicolumn{2}{|l|}{ Model } & $\begin{array}{l}\text { Sum of } \\
\text { Squares }\end{array}$ & Df & $\begin{array}{l}\text { Mean } \\
\text { Square }\end{array}$ & $\mathrm{F}$ & \multicolumn{2}{|c|}{ Sig. } \\
\hline 1 & $\begin{array}{l}\text { Regression } \\
\text { Residual } \\
\text { Total }\end{array}$ & $\begin{array}{r}48.048 \\
67.120 \\
115.167 \\
\end{array}$ & $\begin{array}{r}1 \\
363 \\
364 \\
\end{array}$ & $\begin{array}{r}48.048 \\
.185\end{array}$ & 259.854 & \multicolumn{2}{|r|}{$.000^{\mathrm{b}}$} \\
\hline \multirow{2}{*}{\multicolumn{3}{|c|}{ Model }} & \multicolumn{2}{|c|}{ Un-standardized Coefficients } & $\begin{array}{c}\text { Standardized } \\
\text { Coefficients }\end{array}$ & \multirow[t]{2}{*}{$\mathrm{t}$} & \multirow[t]{2}{*}{ Sig. } \\
\hline & & & $\mathrm{B}$ & Std. Error & Beta & & \\
\hline 1 & $\begin{array}{l}\text { (Cons } \\
\text { Rural } \\
\text { Entrep }\end{array}$ & t) & $\begin{array}{r}1.699 \\
.629\end{array}$ & $\begin{array}{l}.174 \\
.039\end{array}$ & .646 & $\begin{array}{r}9.746 \\
16.120\end{array}$ & $\begin{array}{l}.000 \\
.000\end{array}$ \\
\hline
\end{tabular}

The result in Table 4 shows that entrepreneurship has a significant and positive impact on poverty alleviation. In addition, rural entrepreneurship alone contributes 41.7 percent to poverty alleviation. Durbin - Watson estimated the value of 1.905 clears any doubts as to the existence of a positive first-order serial correlation in the estimated model. The model was built to test the null hypothesis that rural entrepreneurship has no impact on poverty alleviation. F - Statistics of 1259.854 means the total regression plane is statistically significant. Consequently, the null hypothesis is rejected while another hypothesis is accepted. The implication of the finding is that if resources and rural entrepreneurs inclusive in Nigeria, the degree of entrepreneurship development would be high. Table 5: Effect of Rural Entrepreneurship on Employment Generation

\begin{tabular}{|c|c|c|c|c|c|c|c|c|}
\hline Model & $\mathrm{R}$ & R Square & \multicolumn{2}{|c|}{$\begin{array}{c}\text { Adjusted R } \\
\text { Square }\end{array}$} & $\begin{array}{l}\text { Standard Error } \\
\text { of the Estimate }\end{array}$ & \multicolumn{3}{|c|}{ Durbin-Watson } \\
\hline 1 & $.489^{\mathrm{a}}$ & .240 & & .237 & .50399 & & & 1.852 \\
\hline \multicolumn{2}{|l|}{ Model } & \multicolumn{2}{|c|}{ Sum of Squares } & Df & Mean Square & $\mathrm{F}$ & \multicolumn{2}{|c|}{ Sig. } \\
\hline 1 & $\begin{array}{l}\text { Regression } \\
\text { Residual } \\
\text { Total }\end{array}$ & \multicolumn{2}{|c|}{$\begin{array}{r}29.041 \\
92.202 \\
121.244 \\
\end{array}$} & $\begin{array}{r}1 \\
363 \\
364 \\
\end{array}$ & $\begin{array}{r}29.041 \\
.254\end{array}$ & 114.336 & \multicolumn{2}{|r|}{$.000^{\mathrm{b}}$} \\
\hline \multirow[t]{2}{*}{ Model } & & & \multicolumn{3}{|c|}{ Un-standardized Coefficients } & $\begin{array}{c}\text { Standardized } \\
\text { Coefficients }\end{array}$ & $\mathrm{t}$ & Sig. \\
\hline & & & & 3 & Std. Error & Beta & & \\
\hline 1 & $\begin{array}{l}\text { (Constant) } \\
\text { Rural Entre }\end{array}$ & reneurship & & $\begin{array}{r}2.338 \\
.489\end{array}$ & $\begin{array}{l}.204 \\
.046\end{array}$ & .489 & $\begin{array}{l}11.445 \\
10.693\end{array}$ & $\begin{array}{l}.000 \\
.000\end{array}$ \\
\hline
\end{tabular}

The result in Table 5 shows that rural entrepreneurship has a significant and positive impact on employment generation. In addition, rural entrepreneurship independently contributes about $24 \%$ to the employment generation. Durbin - Watson estimated the value of 1.852 eliminates all doubts as to the existence of a positive first-order serial correlation in the estimated model. The model was built to test the null hypothesis that entrepreneurship has no impact on employment generation. F Statistics of 114.334 means the total regression plane is statistically significant. Consequently, the null hypothesis is rejected while another hypothesis is accepted. This suggests that the employment generation is an influence on rural entrepreneurship development. The finding of the study is in line with the study of Kolawole and Torimiro(2005) who assert the rural entrepreneurship development generates employment opportunities, alleviate poverty, forestall rural-urban drift and rural isolation. In another study, Igwe, Adebayo, Olakanmi, Ogbonna, and Aina (2013) reaffirm that entrepreneurship is an alternative paradigm to a quality life, employment generation for the poor. In a comparable study, Onyenechere (2010) notice that entrepreneurship is a stage for generating income for unqualified and skilled workers that otherwise will be unemployed. 


\section{Conclusion}

The study examined the impact of rural entrepreneurship development on poverty alleviation and job creation in Oyo State with specific mention to ten local governments. The current study demonstrated that a chance to create their own luck, degree their impact on rural business opportunities profit attraction, more competitive in the area, self/dependent lifestyle and continue the family tradition are important factors motivating them to build their business in rural areas. The study also confirmed that accessibility of capital and nonavailabilitys of proper information are important challenges facing entrepreneurship development in the absence of government legislation, hard in availing government strategies, technological centers, non-access to resources, transport facility and no availability of correct information are important challenges facing entrepreneurship development in the research region. The study confirmed that entrepreneurship development has a significant impact on poverty alleviation, and employment generation. This suggests that for Nigeria to conquer insurgent, unemployment, guerrilla, and offense, it has to influence on rural entrepreneurship development. The study, therefore, concluded that entrepreneurship development is a strong veritable tool for sustainable financial growth and development.

Based on the conclusion of the research, the following recommendations are made:

i. Rural banks must be established in all rural areas throughout the nation to dish out free loans to rural entrepreneurs.

ii. The promotion of education and financial education of rural entrepreneurs should be encouraged in all regional governments in Nigeria. This may enable rural marketers to be fiscally inclusive.

iii. $\quad$ Ministry of Rural Development and Land Reform should be established in order to develop the essential capabilities which will be necessary to bring about sustainable development in the rural areas. This can go a long way to cut back urban migration syndrome in Nigeria.

\section{References}

Adelakun, J. B. (2013). Rural-Urban Development Dichotomy: A Debate. Being a text Presented on the FlaggOff of Osun Rural Awareness Campaign organized by the State of Osun Local Service Commission. February, $5-8$

Adenutsi, D.E (2009). "Entrepreneurship, job creation, income empowerment and poverty reduction in lowincome economies," Munich Personal RePEc Archive (MPRA), vol. 29569, pp. 1-21.

Akanwa, P. U., \& Agu, C. N. (2005). Entrepreneurship Theory and Practice in Nigeria, Owerri: Resources Development Centre.

Anyadike, N., Emeh, I. E. J., \& Ukah, F. O. (2012) Entrepreneurship Development and Employment Generation in Nigeria: Problems and Prospects. Journal of Education and General Studies 1(4) 088-102

Ariyo, D. (2008). Small Firms are the backbone of the Nigerian Economy. Available online at HTTP:// www.africaeconomicanalysis.org.

Bryden, J., \& Hart, K. (2005) Why Local Economies Differ: The Dynamics of Rural Areas in Europe. The Edwin Mellen Press: Aberdeen, Scotland

Cavanagh, D., Shaw, G., \& Wang, L. (2013). Technical and Vocational Education and Training, and Skills Development for Rural Transformation. In UNESCO-UNEVOC International Centre for Technical and Vocational Education and Training, Revisiting global trends in TVET: Reflections on theory and practice. (pp. 309-335). Bonn, Germany: UNESCO-UNEVOC International Centre for Technical and Vocational Education and Training.

Dabson, B. (2001), "Supporting Rural Entrepreneurship”, Federal Reserve Bank of Kansas City Proceedings, Vol. 27, Federal Reserve Bank of Kansas City, pp. 35-47.

Eso, T. (2015) Solving Nigeria's insecurity challenges with youth integration. The Guardian, Thursday, 18 June 2015.

Fapohunda, T. M. (2012). Women and the Informal Sector in Nigeria:Implications for Development. British Journal of Arts and Social Sciences, 4(1), 35- 45.

Frazier, B.J., Niehm, L.S. \& Stoel. L.(2012). Connecting college learners with rural entrepreneurship opportunities: The rural entrepreneurship teaching unit. Journal of Case Studies in Education, 3, 1-11.

Gartner, W.B., K.G. Shaver, N.M. Carter, P.D. Reynolds (Editors). (2004) sHandbook of Entrepreneurial Dynamics, SAGE publications.

Ighodalo, A.(2012) Poverty and Sustainable Socio-Economic Development in Africa: The Nigerian Experience, European Scientific Journal, 8(26):52-66

Igwe C.N., Adebayo M.S., Olakanmi, O.A., Ogbonna I.G., \&Aina O.S. (2013). Promoting Wealth and Job Creation in Nigeria - Review of the Role of Entrepreneurship. Journal of Sustainable Development Studies, 3(1), 80- 100 .

Jerome, N., \& Bambur, L.M (2013). The Urban and Rural Challenges of Entrepreneurship. Research on Humanities and Social Sciences. 3(5), 57-62

Kolawole, O. D., \& Torimiro, D. O (2005). Participatory Rural Entrepreneurship Development for Grassroots 
Transformation: A Factor Analysis. Journal of Human Ecology, 18(3): 193-198.

Marshall, M. I., \& Samal, A. (2006). "The Effect of Human and Financial Capital on the Entrepreneurial Process: An Urban-Rural Comparison of Entrepreneurs in Indiana." presentation at the American Agricultural Economics Association Annual Meeting, July 23-26.

Matanmi, S., \& Amiden, M. (2005). An Assessment of Competitive Strategies and Growth Patterns of New Enterprises in Nigeria Using the Developing Economy Model. Lagos Organization Review 1(1) 26-32

Mugenda, O., \& Mugenda, G. (2003). Research Methods: Quantitative \& Qualitative Approaches. Acts Press Nairobi - Kenya.

Ocheni, S., Atakpa, M., \&Nwankwo, B.C. (2012). Local Government and Appropriate Capacity Building for Accelerated and Sustainable Rural Development. European Journal of Business and Social Sciences, 1(3), $131-135$.

Olowookere, E.I., \& Elegbeleye, A.O. (2015). Relevance of prosaically behaviours to rural entrepreneurship development in Nigeria. Case Studies Journal. 3(4), 8-15.

Onyemaechi, J. O. (2013). Role of the Informal Sector in Development of the Nigerian Economy: Output and Employment Approach. Journal of Economics and Development Studies, 1(1), 60- 74

Osuagwu, L. (2006) Strategic Management Practices in Nigerian Small Business Enterprises, Proceedings of BAI Conference, Singapore, July 12-14, pp 1-21

Paul, D. G., Datong, C. D., \& Bagobiri, E. (2014). Comparative Analysis of Rural and Urban Start-Up Entrepreneurs in Nigeria. Global Journal of Human-Social Science. 14(1), 29-39.

Petrin, T. (1994). Entrepreneurship as an Economic Force in Rural Development, Keynote Paper.

Sajuyigbe, A.S., \& Fadeyibi, I.O. (2016). Rural Entrepreneurship Development: A Panacea to Sustainable Development in Nigeria. African-Asian Journal of Rural Development. 49(2), 48-63.

Sajuyigbe, A.S. (2017). Influence of Financial Inclusion and Social Inclusion on the

Performance of Women-Owned Businesses In Lagos State, Nigeria. Scholedge International Journal of Management \& Development.4,(3) 18-27.

Saxena, S. (2012), "Problems Faced by Rural Entrepreneurs and Remedies to Solve It", Journal of Business and Management 3(1), 23-29.

Schumpeter, J A. (1951)."The Creative Response in Economic History," Ed. Richard V. Clemence.Port Washington, NY: Kennikat Press, 1951, pp. 216-26.

Slivinski, S. (2012) Increasing Entrepreneurship is a Key to Lowering Poverty Rates. Policy Report, Goldwater Institute, Goldwaterinstitute.org/...PR254\%20increasing\%20entrepreneurship.

Smallbone, D. \& Welter, F. (2006), “Conceptualising Entrepreneurship in a Transition Context", International Journal of Entrepreneurship and Small Business, Vol. 3, No. 2, Inderscience, pp. 190-206.

Sopiko, I., Polina, I., \&Ani, K (2013).Rural Entrepreneurship: Challenges and Opportunities. Bachelor thesis within Business Administration of Jonkopink University

Stathopoulous, S; Psaltopoulos, D. \&Skuras, D. (2004) Rural Entrepreneurship in Europe: A Research Framework and Agenda. International Journal of Entrepreneurial Behaviour and Research 10(6): 404-425 